University of New Haven

University of

New Haven

Digital Commons@ New Haven

History Faculty Publications

History

1989

\title{
Industry, State, and Electrical Technology in the Ruhr Circa 1900
}

Edmund Todd

University of New Haven, etodd@newhaven.edu

Follow this and additional works at: http:// digitalcommons.newhaven.edu/history-facpubs

Part of the History Commons

\section{Publisher Citation}

Todd, Edmund N.. "Industry, State, and Electrical Technology in the Ruhr Circa 1900". Osiris 5 (1989): 242-259.

\section{Comments}

Osiris is Published by The University of Chicago Press on behalf of The History of Science Society. See journal homepage here. 


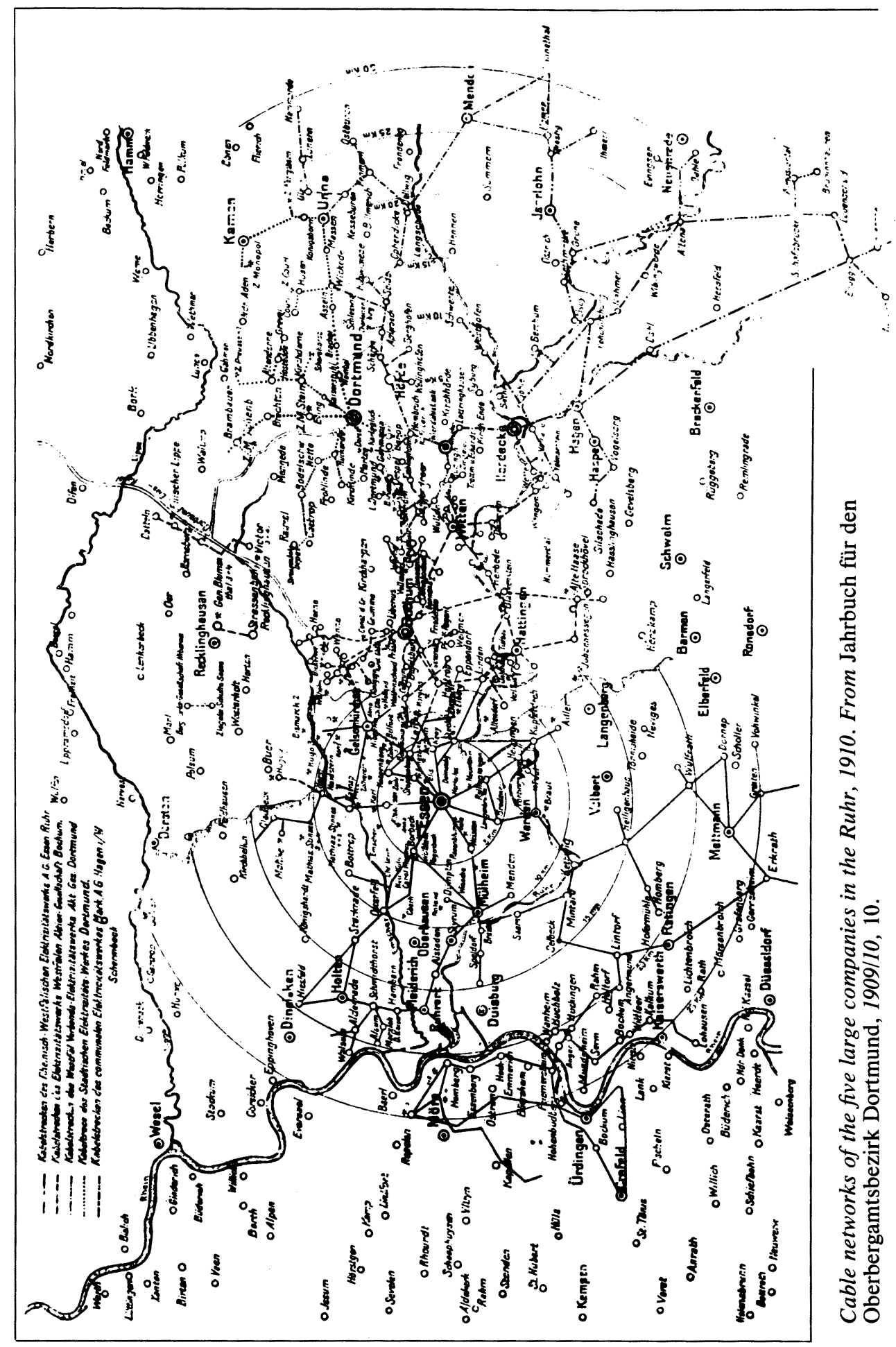




\title{
Industry, State, and Electrical Technology in the Ruhr circa 1900
}

\author{
By Edmund N. Todd*
}

$\mathrm{C}^{\mathrm{a}}$

ONSTRUCTING ELECTRIC POWER and light systems early in the twentieth century challenged existing institutional boundaries. Large-scale technological systems had a wide variety of internal components, the development of which provided new opportunities to serve more customers and wider areas. If controlled by one institution, the growth of a technological system might benefit that institution and not others. Such was the case with electricity. Deployment of electric power systems required renegotiation of institutional boundaries, as leaders of various organized bodies used new technology to promote their own interests.

The problem of analyzing the development of early power systems is not simply one of establishing whether public or private individuals should build public utilities. That is an old and sterile debate. To understand the process of change, it is more fruitful to investigate how people used technology as a political resource in promoting institutional growth and how they resolved their differences. Around 1900 there were at least four different kinds of institutions that competed to build regional power systems in Germany: electrical manufacturers, municipal governments, county administrations, and heavy industrialists. Electrical manufacturers were already involved in building municipal electrical systems, which they often owned or leased. Electricity was also among the many services already supplied by municipal administrations. As alternating-current technology improved, municipal systems expanded and often came into conflict with powerful state officials at the county (Landkreis) level of administration, who oversaw the supply of services to their rural constituents. Finally, industrialists were building power systems to generate electricity for their firms' consumption and sometimes for sale.

The Ruhr provides a useful focus for investigating institutional and technological change. It is a fairly small region, some forty miles long and perhaps twenty miles wide. In the later part of the nineteenth century, the development of heavy industry led it to become one of the most densely populated regions in Germany. The rapid growth of population required new public service systems. During the late 1880 s electric manufacturers approached municipal governments about building electric central stations, but met little success in the Ruhr. The largest cities developed their own public service systems, and several of them expanded

* Department of History, University of New Haven, West Haven, Connecticut 06516.

An earlier version of this paper was presented at the annual meeting of the History of Science Society in October 1986. I would like to thank the Fulbright Commission and the American Council of Learned Societies for research support and Jeffrey Sturchio, Wolfhard Weber, Fritz Ringer, and Robert Glen for their comments. 
their electric power and light systems to serve surrounding county areas. Thus in the Ruhr some of Germany's largest cities and most-powerful municipal administrations came into confrontation with powerful local state officials. County commissioners (Landräte), the linchpins of the Prussian bureaucracy, were instrumental in building regional public service systems and hoped also to control new electric power systems. By the 1890s heavy industrial leaders had organized a regional syndicate, the Rhenish-Westphalian Coal Syndicate, to set production quotas and market coal, and they were seeking ways to rationalize production to reduce costs. Electricity provided an opportunity to integrate productive facilities and to sell a new by-product. New large-scale organizations that were national or even international in orientation dominated heavy industry and electrical manufacturing. In the Ruhr they confronted both the old state apparatus designed for an agricultural state and newer municipal administrative organizations that threatened the power of the state at the local level. ${ }^{1}$

Divergent social, political, and economic goals brought the leaders of the different institutions into conflict, and electrical technology became a powerful instrument in negotiating relations among cities, counties, heavy industrial firms, and to a lesser extent electrical manufacturers. While municipal governments could tie surrounding county areas to themselves through new public service technologies, county governments often fought to maintain their independence from municipal control. Conflict between city and county had an important impact on electrification. County officials hoped to ward off municipal control by creating regional systems, and they had some success, particularly in building systems for fresh water supply and waste water disposal. County governments controlled the use of streets and were crucial in deploying new electric technology. Landräte hoped electricity would promote rural economic development. After 1900 several heavy industrialists added to the confusion by promoting economic concentration in the form of vertically integrated coal, iron, and steel companies. They also threatened to take over several public service technologies and hence to dominate economic and technology policy in the Ruhr. The state opposed them. Conflict was rife. As a result, those who built technological systems also constructed new institutions designed to resolve conflict over the control of electrical technology in the years 1904 to 1909.

\section{ELECTRICAL MANUFACTURERS}

Electrical manufacturers built the first electric central stations in Germany. Emil Rathenau became a patent licensee for the Edison system after visiting the Paris International Electrical Exhibition in 1881. Three years later he built a power station in Berlin. To develop the electric lighting business in Germany, Rathenau organized the Allgemeine Elektrizitäts-Gesellschaft (AEG) in 1887, and the Berlin electric lighting company became an AEG subsidiary. ${ }^{2}$ During the 1880 s the

\footnotetext{
${ }^{1}$ For the development of municipal systems in the Ruhr see Edmund N. Todd, "Technology and Interest Group Politics: Electrification of the Ruhr, 1886-1930" (Ph.D. diss., Univ. Pennsylvania, 1984), pp. 18-72.

${ }^{2}$ For the transfer of Edison's system to Germany and the development of the Berlin power system see Thomas P. Hughes, Networks of Power: Electrification in Western Society, 1880-1930 (Baltimore: Johns Hopkins Univ. Press, 1983), pp. 66-75, 175-200. My intellectual debt to Professor Hughes is extensive.
} 
AEG became an important competitor of Siemens and Halske, which had grown large on telegraphy business. The AEG had close ties to banks from its inception and was quick to develop the kind of managerial hierarchy and multidivisional structure necessary to expand into a new area of business with rapid technological change. Siemens retained its older style of personal management until 1890 , when its founder retired and the company became a leader in developing new managerial structures. Siemens was then able to regain its position, although AEG continued to be its chief rival. After 1900 the two giants of German electrical manufacturing absorbed most of their smaller competitors. ${ }^{3}$

Electrical manufacturers actively sought to sell electric lighting systems to municipal governments in the 1880 s and 1890s. They sometimes established subsidiaries to operate the stations, as the AEG did in Berlin. In the Ruhr, the electrical manufacturer Lahmeyer founded the Rheinisch-Westfälisches Elektrizitätswerk (RWE) in 1898 to operate the central station for the city of Essen. The creation of subsidiaries allowed the inclusion of local interests and local capital, while holding companies financed and organized central station subsidiaries. Electrical manufacturers also provided advice and information on building power systems, in order to promote the sale of equipment by helping cities to establish central stations. Municipal governments needed advice to make sense out of the vast variety of plans resulting from the inchoate nature of the technology. Choosing one electrical manufacturer solved the problem of selecting a system, particularly if the manufacturer promised a good return for its monopoly of city streets. However, city governments had developed a distrust of private capitalists operating public service technologies, particularly in the case of gas lighting. Hence some city governments preferred to hire engineers to build a municipal power system composed of components from several different manufacturers. Dortmund followed this path. ${ }^{4}$

After 1900 electrical manufacturers continued to be important sources of information for municipal and state governments interested in building regional systems. Electrical manufacturers also became important proponents of regional and even national systems. As early as 1912, Georg Klingenberg of the AEG began suggesting that a national system was possible and desirable. He promoted his vision in a series of essays in the German electrical journal Elektrotechnische Zeitschrift before and during the war. Walther Rathenau, son of the founder of the AEG, also promoted a national system through a financial union that, he hoped, would facilitate technological development. Both thought that the state would have to play a key role in building such a system as a means of overcoming local control of the technology. Klingenberg noted in 1913 that Landräte, not mayors, had built regional systems, and as a result the state had to step in to ensure that the organization of the technology could move ahead to the next

\footnotetext{
${ }^{3}$ For these developments in electrical manufacturing see Jürgen Kocka, "Siemens und der Aufhaltsame Aufstieg der AEG," Tradition, 1972, 17:125-142; and Kocka, "Entrepreneurs and Managers in German Industrialization," in The Cambridge Economic History of Europe, 7 vols. (Cambridge: Cambridge Univ. Press, 1978), Vol. VII, pp. 492-589, 709-727, esp. pp. 558-562, 569.

${ }^{4}$ Erich Zweigert, Die Verwaltung der Stadt Essen im XIX. Jahrhundert mit besonderer Berücksichtigung der letzten fünfzehn Jahre (Essen: G. D. Baedeker, 1902), pp. 567-599; "Zusammenstellung der Submissionresultate," 14 Aug. 1895, B 3-1304, pp. 84-85, Stadtarchiv Dortmund; HansDieter Brunkhorst, Kommunalisierung in 19. Jahrhundert dargestellt am Beispiel der Gaswirtschaft in Deutschland (Munich: Tuduv, 1978); and C. Döpke, Das städtische Elektrizitätswerk in Dortmund (Dortmund: F. W. Ruhfus, 1900).
} 
stage of development in a national system. Both Klingenberg and Rathenau wanted industry - that is, electrical manufacturers-to run the system created by state intervention. They sought institutional allies to gain control of a national grid. 5

\section{MUNICIPAL GOVERNMENTS}

Industrial development in the western provinces after the 1870 s brought significant changes in the distribution of population in Germany from the east to the west and from rural to urban areas. Growing cities developed housing, transportation, water, sewage, health, and lighting problems. Throughout Germany, municipal governments became much more active in dealing with urban problems and became noted for their "municipal socialism." Municipal governments began providing services and even began operating businesses such as slaughterhouses to generate income so that cities could provide other services without raising taxes. Supplying gas and water to city populations was among the earliest tasks taken up by municipal governments. During the 1850s Bochum and Duisburg established the first gas facilities in the Ruhr. In 1864 Essen opened the first waterworks, and in the 1870 s other cities followed its lead. Municipal administrations became more professional and expanded in size as they increased services. After unification of Germany in 1871, several cities gained independence from county control: Essen in 1873, Duisburg in 1874, Dortmund in 1875, and Bochum in 1876 . These cities no longer reported to Landräte and thus had more freedom from direct state control. ${ }^{6}$

Essen and Dortmund provide good examples of how municipal administrations and mayors became involved in solving municipal problems. In Essen heavy industrial development brought a large number of health, housing, and welfare problems. Attempts on the part of private citizens to deal with those problems proved unsuccessful in the 1860 s and 1870 s, and as a result the city administration became increasingly active. Erich Zweigert, mayor from 1886 to 1906, accelerated this development, so that by 1914 the municipal government touched almost all aspects of city life. He took decisive steps to solve the housing problem by outmaneuvering the Landrat of the county of Essen to double the area of the city in 1901 . The increase in territory allowed the city to plan housing necessary for its rapidly growing population. Mayor Wilhelm Schmieding of Dortmund also exemplified the qualities of the new, active mayors throughout Germany. He believed that city governments should provide water, gas, electricity, transporta-

\footnotetext{
${ }^{5}$ Helga Nussbaum, "Versuche zur reichsgesetzlichen Regelung der deutschen Elektrizitätswirtschaft und zu ihrer Überfuhrung in Reichseigentum 1909 bis 1914," Jahrbuch für Wirtschaftsgeschichte, 1969, Pt. 2, pp. 117-203; Georg Klingenberg, "Richtlinien für den Bau großer Elektrizitätswerke mit Dampfbetrieb," Elektrotechnische Zeitschrift, 1912, 33:731-735, 766-769, 796-800, 814-818, 880-882; Klingenberg, "Elektrische Großwirtschaft unter staatlicher Mitwirkung," ibid., 1916, 37:297-298, 314-317, 328-333, 343-348; Walther Rathenau, "Denkschrift, betreffend ein Reichs-Elektrizitätsmonopol," 13 Nov. 1913, Deutsches Zentralarchiv Potsdam, Reichskanzlei, Vol. 598a, pp. 372-379v, rpt. in Nussbaum, "Versuche," pp. 192-203; and Georg Klingenberg, "Elektrizitätswerke und Überlandzentralen," Elektrotech. Z., 1913, 34:315-317.

6 Wolfgang R. Krabbe, "Munizipalsozialismus und Interventionsstaat: Die Ausbreitung der städtischen Leistungsverwaltung im Kaiserreich," Geschichte in Wissenschaft und Unterricht, 1979, 30:265-283; and Helmuth Croon, "Städtewandlung und Städtebildung im Ruhrgebiet im 19. Jahrhundert," in Aus Geschichte und Landeskunde: Forschungen und Darstellungen (Bonn: Röhrscheid, 1960), pp. 484-501.
} 
tion, parks, and public welfare institutions. The administrations in Essen and Dortmund, like other municipal administrations, had become quite interventionary in their relationships to economic and social development by $1900 .^{7}$

To solve local problems, municipal governments often sought to work through private companies. Before the 1850 s municipal governments avoided risks on new gas technology by having private companies introduce gas lighting systems. Municipal governments began considering municipal ownership as a means of increasing their incomes from gas, but during the 1860 s most cities continued to allow private ownership of gas lighting systems and signed new long-term contracts to gain expanded and improved service. As they increased their economic activities, municipal administrations began promoting technological change in the gas lighting industry to improve services further. Private owners were less interested in upgrading their systems, however, since they were receiving steady incomes and wished to amortize investment in existing facilities. Thus during the 1880 s and 1890s many cities purchased gas companies in order to improve lighting service. Previously, civil servants had not thought it appropriate to spend tax money on risky ventures, and they were wary of attempting to manage productive facilities. By the 1880 s and 1890 s, however, gas technology had largely proved itself, and municipal administrations needed new sources of income to help finance other services. Municipal administrations solved the management problem by creating a separate administrative structure for the gasworks. There were also a number of legal forms available, such as partnerships, companies with limited liability (Gesellschaften mit beschränkter Haftung), and joint stock companies (Aktien-Gesellschaften), that provided other institutional forms for managing a productive facility. These forms were more important for electrification. ${ }^{8}$

Private capitalist control of the technological system could prevent technological change. In Dortmund, for instance, the municipal government could not persuade the privately owned gas company to introduce electric lighting in the early 1890s. The gas company received judicial support for its assertion that its contract with the city gave it exclusive control of municipal streets for lighting systems, forcing the city to renegotiate its contract with the company. In exchange for a longer contract and the right to deliver gas for heating and cooking purposes, the gas company agreed to give up its exclusive use of city streets for lighting and to allow the city to begin operating its own electric lighting system. ${ }^{9}$ Essen's experience with electric traction illustrates the same problem: private companies often refused to improve their technological systems and sometimes prevented technological change. Because no one in Essen's municipal administration thought that a traction system could pay for itself, the city had developed a contract to induce private parties to build a system for the city. In the early 1890 s the city renegotiated the contract to persuade the private company to build an electric rather than a steam traction system, but since the contract did not

\footnotetext{
${ }^{7}$ Eugene Charles McCreary, "Essen 1860-1914: A Case Study of the Impact of Industrialization on German Community Life" (Ph.D. diss., Yale Univ., 1964); and Friedrich Horstmann, "Dr. phil. h.c. Wilhelm Schmieding, Oberbürgermeister der Stadt Dortmund 1886-1910," Beiträge zur Geschichte Dortmunds und der Grafschaft Mark, 1962, 58:304-324.

${ }^{8}$ Brunkhorst, Kommunalisierung (cit. n. 4).

9 For a general discussion of private gas company reactions to electricity see ibid., pp. 142-147. For Dortmund see Todd, "Technology and Politics" (cit. n. 1), pp. 27-30, 38-39.
} 
preserve any direct role for the municipal administration in the company, the city had no leverage in dealing with the company. Soon after its completion the traction system proved inadequate. The city administration spent the later half of the 1890s trying to find a way to force the private company to improve and expand the system to serve areas of the city that might not provide as high a rate of return on capital investment as other, more densely populated areas. ${ }^{10}$ Municipal governments learned that private companies might take the initial risk of introducing new technology but might not continue to do so if they were making profits on their initial investment. Experience during the 1890 s with private companies proved important after 1900, when heavy industrialists began taking over public utilities.

There was another aspect of municipal development that proved important in electrification. Essen and Dortmund had evolved as administrative, economic, and transportation centers. Dortmund was the seat of two state organizationsthe Superior Mining Office (Oberbergamt) and the Superior Post Office (Oberpostdirektion) - and its Guild Chamber (Handwerkskammer) provided further regional significance. Essen was the seat of various mining associations, the Ruhr's railroad administration, and regional organizations for water and sewage. Its banks made Essen a financial center for the Ruhr. Essen and Dortmund also had chambers of commerce, whose importance reached beyond municipal boundaries. Because they played such key roles in their areas, Essen and Dortmund eventually incorporated almost their entire county areas, organized in the early nineteenth century. Both cities also had integrated elites who supported municipal administrations that looked beyond city boundaries to solve regional problems. Mayors Zweigert and Schmieding were therefore both instrumental in introducing electrical technology in the form of alternating-current systems that would enable their cities to serve customers beyond municipal boundaries. However, municipal control of regional technological systems threatened the independence of surrounding communities and counties, and thus it might prevent the development of regional technological systems. Aware of this problem, Mayor Zweigert had the Landrat of the county of Essen lead negotiations for the streetcar system that would serve county and city. He also recognized that private control of the streetcar system would overcome the fears of Essen's neighbors. ${ }^{11}$

\section{LANDRÄTE AND THE STATE}

In the late 1870 s the state in Germany turned away from its earlier laissez-faire orientation and became more active in the economy. One outcome of this change was a new tariff policy in 1879 to protect certain industries and east Elbian agriculture. In the early 1890 s the new Reich chancellor, Leo von Caprivi, lowered agricultural tariffs as part of a government economic policy to expand opportunities for German industry in foreign markets and increase employment. His new

${ }^{10}$ Erich Zweigert to town council (Stadtverordnete-Versammlung), 28 Dec. 1902, Rep. 102, I, 1274, pp. 38-83, Stadtarchiv Essen.

11 Croon, "Städtewandlung" (cit. n. 6); Helmuth Croon, "Zur Entwicklung der Städte im 19. und 20. Jahrhundert," Studium Generale, 1963, 16:565-575; Croon, "Bürgertum und Verwaltung in den Städten des Ruhrgebiets im 19. Jahrhundert," Tradition, 1964, 9:23-41; Edmund N. Todd, "A Tale of Three Cities: Electrification and the Structure of Choice in the Ruhr, 1886-1900," Social Studies of Science, 1987, 17:387-412; and Zweigert to town council, 28 Dec. 1902 (cit. n. 10). 
policies did help produce rapid industrial development, which led to an important debate concerning Germany's shift from an agricultural to an industrial state. In part, the government became increasingly involved in response to real problems faced by the elites holding power as the population was moving into industry and electoral politics was producing an increasingly large faction of Social Democrats in the Reichstag. Some groups opposed the development of an industrial and urban society as an unhealthy threat to the Prussian state and German culture. Conservatives took up these ideas in the 1890 s to buttress the position of the aristocracy and agricultural interests. A rural-romantic orientation became popular among some groups in German society, including Prussian bureaucrats, who to a large extent represented the interests of the aristocracy. ${ }^{12}$

The antiurban and anti-industrial orientation of Prussian state officials affected the development of local state institutions, particularly in the industrializing and urbanizing areas. Prussian state institutions reached down to the local village; thus Prussian ministers in Berlin could, in theory, use the bureaucracy to exert a substantial degree of local control. The most important positions in the exercise of local control were the district president (Regierungspräsident) and the Landrat (county commissioner). The district president reported directly to Berlin and directed the administrative activities of the Landräte in his government district (Regierungsbezirk). The district president did not have a legislative body through which he could create new local legislation but instead had to work through Landräte to create local responses to local problems. Counties had a level of self-government (Selbstverwaltung) over which Landräte presided; Landräte thus had a dual function. They were administrators who reported to a district president and ultimately to the minister of the interior in Berlin, but they also had a certain amount of local autonomy owing to their ability to direct legislation in their counties. Landräte could function as entrepreneurs by creating organizations to provide services for their counties, and they could join together to build regional systems. Landräte also had a degree of autonomy because of their local ties. In order to bind local government to the state, the Prussian minister of the interior often chose Landräte from the area in which they were going to serve, making sure, however, to choose persons loyal to the conservative Prussian state. Thus Landräte were tied ideologically to the agrarian-dominated, conservative state bureaucracy, but because of their local connections and local power they expressed their administrative and entrepreneurial functions differently depending on the region in which they worked and the kind of local clientele they served. ${ }^{13}$

The antiurban orientation of the conservative state preserved the position of Landrat and hence state power in industrial regions. Until the 1870 s all cities in the Ruhr were under the administrative direction of Landräte. Then in rapid succession Essen, Dortmund, Duisburg, and Bochum received full city rights and

\footnotetext{
12 For a survey of the literature on the relationship between the aristocracy and the bureaucracy see Gary Bonham, "State Autonomy or Class Domination: Approaches to Administrative Politics in Wilhelmine Gemany," World Politics, 1983, 35:631-651.

${ }^{13}$ Herbert Jacob, German Administration since Bismarck: Central Authority versus Local Autonomy (New Haven, Conn.: Yale Univ. Press, 1963), pp. 12-62; Heinz Günther Steinberg, "Zur Verwaltungsgeschichte des Ruhrgebietes," in Politik und Landschaft, ed. Walter Foerst (Cologne/Berlin: Grote, 1969), pp. 177-215; and Lysbeth W. Muncy, "The Prussian Landräte in the Last Years of the Monarchy: A Case Study of Pomerania and the Rhineland in 1890-1918," Central European History, 1973, 6:299-338.
} 
became independent of Landräte supervision. After the 1870s, however, although population density increased rapidly in the Ruhr, few cities gained independence. The position of Landrat gave the state more direct control over workers and local economic activity than it would have with a mayor in an independent city. Mayors were often too liberal as well. Prussian policies kept large numbers of people under the direct control of state officials. In 1911 Hamborn, north of Duisburg, held the distinction of being the largest Prussian "rural community" (Landgemeinde), with 100,000 inhabitants. At that time there were ninety-nine "rural communities" in Prussia with more than 10,000 inhabitants, all in industrial areas. The Rhineland and Westphalia together had fifty-one, while other areas of Prussia contained three hundred "cities" with fewer than 2,500 inhabitants. ${ }^{14}$

Landräte in the Ruhr opposed the change from an agrarian to an industrial and urban nation and hoped to use modern technology to direct change along other paths. Karl Gerstein, Landrat in the county of Bochum from 1900 to 1919, believed that farmers were crucial for a healthy state but were losing ground. His position as Landrat gave him the means to shape industrial and urban development so as to preserve the independence of rural communities. He opposed the growth of large cities through incorporation of neighboring communities because the process destroyed local self-government and the communal, economic, and cultural life necessary for a healthy society. To oppose the expansion of large cities and preserve the autonomy of rural communities and small towns, Gerstein worked to establish regional rather than municipal public utility systems. This was a sound policy that helped overcome the parochial orientation of cities. The influx of laborers into the Ruhr's growing industrial productive sites placed significant demands on local budgets to provide necessary services. Through public service systems for gas, water, transportation, and electricity, towns and cities tried to increase their own incomes and at the same time prevent a distribution of income to surrounding communities faced with the same kinds of financial problems. Landräte could work against such parochial policies because they served a larger area, the county, than did municipal governments. ${ }^{15}$

Landrat Gerstein was a key figure in organizing a number of regional systems to deal with the problems of urbanization and industrialization. In 1902 he organized a public water supply system, the Verbandswasserwerk $\mathrm{GmbH}$, to enable financially weak communities in the counties of Bochum, Gelsenkirchen, and Hattingen to gain their independence from the city of Bochum by securing a common supply of water. The business form chosen enabled each community to hold a block of shares and to include new communal groups through the sale of stock. ${ }^{16}$ Gerstein also took decisive steps to solve regional sewage and waste water problems. The population along the Emscher River had increased from

${ }^{14}$ Helmuth Croon, "Die Verwaltungsmäßige Gliederung des mittleren Ruhrgebietes im 19. und 20. Jahrhundert," in Bochum und das mittlere Ruhrgebiet, ed. Gesellschaft für Geographie und Geologie Bochum (Paderborn: Ferdinand Schöningh, 1965), pp. 59-64, on p. 61.

${ }^{15}$ Alfred zur Nieden, "Karl Gerstein," Rheinisch-Westfälische Wirtschaftsbiographie, 13 vols. (Münster: Aschendorff, 1932-), Vol. I, pp. 487-518; Franz-Josef Brüggemeier, Leben vor Ort: Ruhrbergleute und Ruhrbergbau, 1889-1919 (Munich: C. H. Beck, 1983), pp. 32-41.

16 Nieden, "Gerstein," pp. 502-504; and Ludwig Aschoff, "Die Gruppenwasserversorgung in rheinisch-westfälischen Industriebezirke durch das Verbandswasserwerk," Technisches Gemeindeblatt: Zeitschrift für die Technischen und Hygienischen Aufgaben der Verwaltung, 1905, 7:337-341. 
35,000 in 1870 to $1,340,000$ in 1900 as mining activities moved northward in the Ruhr. Mining caused the ground to settle, thus increasing the swampy conditions along the slow-moving Emscher. As Regierungsassessor (government assessor) in charge of water management in the government district of Arnsberg before becoming Landrat, Gerstein had recognized the need for a regional solution to deal with problems in a zone divided among 2 provinces, 3 government districts, 6 cities, 8 counties, $43 \ddot{A m t e r}$ (offices), and 137 local communities. In 1904 the Emschergenossenschaft was established to regulate the Emscher so as to solve pressing problems resulting from urbanization and industrialization while preserving the autonomy of the communities between the Emscher and the Ruhr rivers. Public and private organizations producing the sewage and waste water contributed funds, but control was in the hands of the participating cities and Landkreise. Gerstein became the chairman of the Genossenschaft in 1906. ${ }^{17}$

Landräte like Gerstein worked against the narrower perspectives of municipal governments in developing organizations that could deal with regional problems. These organizations provided potential models for regional electric light and power systems. They also reflected the opposition of Landräte and other state officials to urbanization and industrial concentration. Landräte had already found the means for building Ruhr-wide technological systems to maintain local control and promote local development when heavy industrialists began challenging state power in the Ruhr. These industrialists were to present a fourth institutional niche for the building of a regional electric power and light system.

\section{VERTICAL INTEGRATION AND ELECTRICITY}

One of the key issues in German history concerns the development of large-scale industries with complex managerial hierarchies. One current line of thought is that modern multiunit enterprises developed as a means of overcoming the advantages that England had on the world market. Banks helped surmount capital shortages by concentrating capital from a large number of people, while joint stock companies enabled a firm to draw on savings of small shareholders to invest in new forms of production technology that would allow the Germans to compete with the English. Increasing the scale of production required new means of managing large numbers of people involved in diverse stages of production, sometimes in different locations. These changes were perhaps most evident in German steel, iron, and coal production, particularly in the Ruhr. There, coal mining required concentration of capital, and as a result, banks were involved early in financing the introduction of deep shaft mining. Iron and steel companies developed a diverse line of goods to attract customers and sought to integrate production from raw materials to finished product. Some iron and steel manufacturers purchased coal mines to build vertically integrated companies. A further incentive to technological integration of the firm came with attempts to cut down on fuel costs from heating iron ore, pig iron, and then steel in several different stages of production from blast furnace to finished product. Production in "one

\footnotetext{
17 Heinrich Helbing, "Die Emschergenossenschaft, Essen," in 25 Jahre Emschergenossenschaft, 1900-1925, ed. Helbing (Essen: Emschergenossenschaft, 1925), pp. 1-17; Hans Luther, "Vorwort: Die Emschergenossenschaft als besondere Verwaltungsform des Ruhrgebietes," ibid., pp. v-xii; and Alexander Ramshorn, "Die Emschergenossenschaft," in Fünfzig Jahre Emschergenossenschaft. 1906-1956, ed. Ramshorn (Essen: Emschergenossenschaft, 1957), pp. 33-82.
} 
heat" required extensive financial resources and managerial control to ensure a smooth flow of material through the company. ${ }^{18}$

During the 1890s heavy industrial companies searched for ways of reducing costs. Gas engines provided one means of turning a waste product into a usable commodity. They could burn either blast-furnace gas or coking gas, although they usually used blast-furnace gas, since coking gas could be sold more profitably for lighting. In the late 1890s the Hörder Verein introduced the first blastfurnace gas engine. Within ten years engines producing up to 4,000 horsepower allowed companies to utilize blast-furnace gas to power blast equipment or electric dynamos. This development in the iron and steel industry meant that large companies were not readily available as consumers of publicly generated electricity. But they could sell electricity. Coal mines also developed an electricgenerating capacity in order to utilize waste coal that could not be sold or otherwise used. They introduced turbines and exhaust turbines, using steam from other turbines, to generate electricity. Both gas engines and waste coal-fired turbines improved the energy efficiency of the Ruhr's heavy industry. ${ }^{19}$

After 1900 heavy industrial companies began building electric transmission and distribution systems in the Ruhr. A large company often had productive facilities in several different areas, and electric transmission systems allowed a company to tie facilities together to improve overall efficiency in a technologically integrated system. A company could also improve its use of its installed equipment by providing electricity to neighboring communities, since industry and local communities had different load patterns. Industry showed peak periods of consumption in the early morning and early afternoon, whereas towns had a lighting load in the early evening. Industrial systems supplying towns could therefore utilize equipment more fully, thus increasing the income from fixed capital investments. Towns could gain a cheap source of electricity without having to build or expand municipal power stations. ${ }^{20}$

Several companies promoted this model of electrification, but the most important example was the Rheinisch-Westfälisches Elektrizitätswerk (RWE). The electrical manufacturing firm Lahmeyer had established the RWE in 1898 to operate the electric power and light system in the city of Essen. In 1902, to overcome financial difficulties, Lahmeyer sold its shares in the RWE to two leading heavy industrialists, Hugo Stinnes and August Thyssen. The RWE built its first power station on a Stinnes mine, from which it drew steam to circumvent the Rhenish-Westphalian Coal Syndicate's coal quotas and prices. After 1902 the RWE also began transmitting electricity to another Stinnes mine, which became the first mine in the Ruhr to depend wholly on an outside source of electricity. The RWE supplemented its own generation of electricity by arranging

\footnotetext{
18 Jürgen Kocka, "The Rise of the Modern Industrial Enterprise in Germany," in Managerial Hierarchies: Comparative Perspectives on the Rise of the Modern Industrial Enterprise, ed. Alfred D. Chandler, Jr., and Herman Daems (Cambridge, Mass.: Harvard Univ. Press, 1980), pp. 77-116; and Kocka, "Entrepreneurs and Managers" (cit. n. 3), pp. 555-589.

19 For the development of gas engines and heavy industrial power systems see $\mathrm{H}$. Bonte, "Einfluß der Großgasmachine auf die Entwicklung der Hüttenwerke," Zeitschrift des Vereines Deutscher Ingenieure, 1908, 52:1912-1916; and Die Entwickelung des Niederrheinische-Westfälischen Steinkohlen-Bergbaues in der zweiten Hälfte des 19. Jahrhunderts, ed. Verein für die Bergbaulichen Interessen, 12 vols. (Berlin: Springer, 1902-1905). Vol. VIII, pp. 417-719.

20 Professor Baum, "Beiträge zur Frage der Krafterzeugung und Kraftverwertung auf Bergwerken," Glückauf, 1906, 42:1001-1015, 1033-1047, 1083-1088, 1137-1155, on pp. 1144-1155.
} 
energy exchange contracts with several heavy industrial firms (DeutschLuxemburgische Bergwerks- und Hütten-AG, Gewerkschaft Deutscher Kaiser, and the Gelsenkirchener Bergwerks-AG). Stinnes sought to build the RWE into a company serving the area from the Lippe River to Aachen. It looked to some like the ideal combination of heavy industrial generation of electricity and industrial and communal consumption. Stinnes thus promoted a fourth model: regional electrification in private hands and closely tied to heavy industrial interests. ${ }^{21}$

\section{BUILDING A REGIONAL SYSTEM}

By 1902 there were four institutional structures that might have provided a basis for a new regional technological system in the Ruhr. At this time alternatingcurrent transmission systems combined with the increasing size of steam turbines permitted and perhaps even required regional systems, which could supply a variety of customers with varied demand schedules and hence allow a more balanced load on equipment. Municipal systems could expand outward and serve surrounding areas, but state officials wanted to avoid economic and demographic concentration in cities. In the Ruhr, Landräte had helped organize new institutions to deal with regional problems by maintaining local control and opposing urban concentration, and they hoped to do the same for electricity. Electrical manufacturers offered a third institutional structure, one that would place control in their hands and might avoid urban or state control. Heavy industrialists promoted development of a regional system, but one narrowly tied to heavy industrial goals. From 1904 to 1909 in the Ruhr, members of these four types of organizations struggled to build and control an electric power and light system for the Ruhr. The confrontation over the new technology involved important institutional and political stakes and could not be resolved within the existing institutional framework, or within one technological system.

The immediate impetus for conflict came from Stinnes and Thyssen. They began to expand the RWE to serve an area that encompassed the Ruhr at the very time that they were trying to reorganize heavy industry there. The RWE provided a technological means for the reorganization. In 1905 the company began building its second power station on a mine controlled by Stinnes near Dortmund. It sought to supply several of Stinnes's holdings around Bochum and gained customers near its new Westphalian power station. The power company also tried to build lines to connect its new power station and its old one in Essen. ${ }^{22}$ Concurrently, to implement their organizational goals the two heavy industrialists tried to take over one of the largest coal mining companies in the Ruhr, Emil Kirdorf's Gelsenkirchener Bergwerks-AG. When this attempt failed, they helped Kirdorf convert his company into a vertically integrated mining and foundry company. Kirdorf also signed an energy exchange contract with the

${ }^{21}$ For the early development of the RWE see Zweigert, Verwaltung (cit. n. 4), pp. 567-599; Camillo J. Asriel, Das R.W.E., Rheinisch-Westfälisches Elektriziätswerk A.G., Essen a. d. Ruhr: Ein Beitrag zur Erforschung der modernen Elektrizitätswirtschaft (Zurich: Girsberger, 1930), pp. 1-24; and Ernst Henke, Das RWE nach seinen Geschäftsberichten, 1898-1948 (Essen: RWE, 1948), pp. 5-27. For a report of Stinnes's goals see Arthur Schreiber (district president of Düsseldorf), “Besprechung über die Versorgung des rheinisch-westfälischen Industriegebietes mit Elektrizität durch das Rheinisch-Westfälische Elektrizitätswerk,” 8 Dec. 1905, Regierung Düsseldorf 9892, pp. 294-298, Hauptstaatsarchiv Düsseldorf (hereafter HStA Dü); and Baum, "Beiträge," pp. 1007, 1153.

22 Asriel, R.W.E., pp. 7-8; Henke, RWE, pp. 15-19. 
RWE and joined its board of directors. Because of Stinnes's maneuvers in heavy industry and electric power, state officials became concerned about the state's relationship to the economy and to economic leaders in the Ruhr. To protect their power, Prussian officials sought to purchase a controlling interest in a large coal mine (Bergwerksgesellschaft Hibernia) but met stiff opposition from many heavy industrialists in a confrontation that became known as the "Hibernia Affair." ${ }^{23}$ State officials also became anxious about the effect Stinnes might have on electrification, which they saw as related to his maneuvers in heavy industry. ${ }^{24}$

The Ruhr fell mostly within the government districts of Düsseldorf in the Rhine province and Arnsberg in Westphalia, and their presidents organized the initial state reaction to the RWE. They opposed the private monopoly of a public service. The district president in Arnsberg thought such a monopoly would become a "pressing burden" on the public, and he observed that the section of heavy industry connected to the RWE exerted "great influence" on many communities in the Ruhr. That section would support the RWE's expressed concern for the common good and "cultural progress" only so long as it did not conflict with heavy industry's "financial interests." The district president in Düsseldorf believed that a private monopoly would make the Ruhr's economic development depend on the RWE. To protect local communities from "adroit business representatives," the district presidents sought to ensure adequate technical advice by coordinating responses to the RWE. ${ }^{25}$ They also gained the right to review the RWE's petitions to lay transmission and distribution lines on railroad property. This important concession prevented the RWE from circumventing a community's main bargaining chip, control of streets for supply systems. If the RWE could use railroad rights of way, it could build up a set of powerful local customers who might insist that a community sign a supply contract favorable to the RWE and not to the community. ${ }^{26}$

Despite similarities in views and tactics, negotiations in the two areas followed different paths. The district president of Düsseldorf called several meetings in fall 1905 with leading electrical manufacturers to discuss an electric supply system that would be independent of Stinnes and the RWE. Topics included a loose alliance of systems rather than one big system controlled by the RWE, and a system based on a coal mine on the left bank. Georg Klingenberg, who later promoted a national grid, argued that there were limits in size above which it was not economical to build a power system. Hence he discounted the alliance of systems and supported a system serving the left bank. The district president identified a key characteristic of any such system: it would have to match RWE

${ }^{23}$ For the changing relationship between state and industry and the "Hibernia Affair" see Charles Medalen, "State Monopoly Capitalism in Germany: The Hibernia Affair," Past and Present, 1978, 78:82-112.

${ }^{24}$ See the draft report, Privy Councillor Putch (Government District of Düsseldorf) to Minister of Public Works, 16 Jan. 1905, Regierung Düsseldorf Präsidialbüro 1068, pp. 5-12, HStA Dü.

${ }^{25}$ Franz von Coels (district president of Arnsberg) to Hugo Stinnes, 8 Dec. 1905, Regierung Düsseldorf 9892, p. 318, HStA Dü; Coels to Minister of the Interior, 7 Dec. 1905, Oberpräsidium 6238 , Staatsarchiv Münster; Arthur Schreiber to Minister of the Interior, 4 Dec. 1905, Regierung Düsseldorf 9892, pp. 248-253; and Coels to provincial president of Westphalia (Eberhard von der Recke), 31 May 1904, Oberpräsidium 6238. For the district of Düsseldorf see Schreiber to "Landräte, Oberbürgermeister, und Bürgermeister," 27 May 1904, Regierung Düsseldorf 9892, pp. 11-12.

26 In August 1905 the minister of public works ordered the railroad administration to consult with the district presidents before allowing the RWE to deliver electricity from cables on railroad property; see Minister of Public Works to District President in Düsseldorf, 15 Aug. 1905, Regierung Düsseldorf 9892, p. 99. 
prices in order to persuade communities to sign supply contracts, since he could not force them to sign. ${ }^{27}$ But the RWE already had a number of advantages. By 1905 it had built an extensive electric power and light system in the Rhine province and in Westphalia and could offer low prices to potential customers. Moreover, a communal government did not control it. Hence, the RWE could gain counties as customers in a way that a municipal system could not, and municipal governments, in turn, could avoid county control by joining the RWE's system. For instance, the mayor of the recently established Westphalian city of Gelsenkirchen looked to the RWE for assistance in securing his independence from Landräte. In promoting its version of a regional system, the RWE supported the mayor of Gelsenkirchen in his bid to open up surrounding county areas for future incorporation. The RWE also supported Landräte against mayors where they were the more powerful local figures, as it did the Landrat in the Rhenish county of Kempen in 1910. For this tactic to succeed, the RWE had to change its business structure to include communal interests. This change did not come, however, in time to circumvent opposition in Westphalia, and as a result the RWE was unable to include the entire Ruhr in its system. ${ }^{28}$

In the district of Arnsberg, the district president, Landräte, and mayors worked together against the Rhenish, heavy industrialist-dominated RWE. The district president played a key role in promoting the development of electrification under the control of local state and municipal officials. He hoped to keep public service systems in public hands, and he was able to find powerful allies among the Landräte of the district. One of the most important Landräte was Karl Gerstein in the county of Bochum. He helped organize a number of meetings to coordinate responses to the RWE's expansion. Gerstein wanted a system for the entire Rhenish-Westphalian industrial area in order to maintain local autonomy. He sought to build a broad consensus for regional electrification among officials in Berlin, in regional and local levels of administration, and in local state agencies concerned with mining, canals, and railroads. Gerstein also requested support from the most important regional coal organization with the argument that a unified regional system would benefit the coal industry. ${ }^{29}$

A regional solution for the Ruhr in the form of a technological system controlled by Landräte failed. The communities could not finance the system. Perhaps more important, the RWE was already too strong in the Rhenish section of the Ruhr, and heavy industrialists opposed state control. Gerstein believed that the communal project required the "unlimited cooperation of industry in the entire region," because each mine shaft would soon be generating electricity. Only

${ }^{27}$ For discussions concerning the left bank see "Besprechung, betr. Lieferung von Elektrizität für das rheinisch-westfälische Industriegebiet durch das Rheinisch-Westfälische Elektrizitätswerk in Essen," 30 Nov. 1905, Regierung Düsseldorf 32044, pp. 73-74, HStA Dü; other reports are contained in Regierung Düsseldorf 9892, pp. 282-287, 294-298, 313-314, ibid.; and "Besprechung über die Verhandlungen betr. die Versorgung des rheinisch-westfälischen Industriegebietes mit elektrischer Kraft," 23 Dec. 1905, Oberpräsidium 6238, Staatsarchiv Münster.

${ }^{28}$ For Gelsenkirchen see Regierung Düsseldorf 32044, pp. 182-184, HStA Dü; and Bernard Goldenberg, "Besprechung mit Herrn Oberbürgermeister Machens wegen des Demarkation Westfalen," 8 Jan. 1907, Stinnes Nachlass, 316/1, Archiv für Christlich Demokratische Politik, Adenauer Stiftung, Bonn. For Kempen see W. von Tippelskirch to Landrat Hermann Strahl, 7 May 1910, Stinnes Nachlass, 150/1, ibid. Other mayors were not inclined to follow Gerstein's lead; see District President in Arnsberg to Minister of the Interior, 7 Dec. 1907, Oberpräsidium 6238, Staatsarchiv Münster.

${ }^{29}$ Karl Gerstein to District President in Düsseldorf, 10 Aug. 1905, Regierung Düsseldorf 9892, pp. 100-101, 103, 105-106, HStA Dü; Gerstein to Rheinisch-Westfälisches Kohlensyndicat, 12 Aug. 1905, Oberpräsidium 6238, Staatsarchiv Münster. 
if the coal mines provided electricity for a communal system to distribute could the project supply electricity at the lowest possible rates. But, Gerstein noted, the Rhenish-Westphalian Coal Syndicate rejected collaboration, as did individual mines and the industrial corporations controlled by Stinnes, Thyssen, and Kirdorf. Thus collaboration with an influential segment of the Ruhr's heavy industry was not possible. ${ }^{30}$ The institutional context worked against either heavy industrial or state control of a power system to unify the Ruhr.

Partial resolution of the conflict came through a blurring of the boundary between state and industry in both sections of the Ruhr. Stinnes reorganized the RWE to include municipal and county participation. In 1904 and again in 1905 he proposed that the Prussian state purchase shares in the RWE and place representatives on the company's board of directors. Such a maneuver might have helped the RWE politically by redefining institutional stakes in the conflict over the technological system. But the Prussian ministers decided in 1905 and again in early 1906 not to participate in the RWE because of local opposition to the company, particularly in Westphalia. ${ }^{31}$ The RWE instead began modifying its institutional makeup by selling stock to cities and counties and by placing representatives of these potent institutions on the RWE's board. This maneuver solved political problems by providing the semblance of public influence over the RWE. State agencies had sided with communal governments against the RWE, but the RWE could gain state support if it had communal allies. The new mixed business form also helped the RWE financially. It could gain new territory by exchanging RWE stock and a position on the board for communally owned power systems and communally guaranteed loans. ${ }^{32}$ Institutional innovation allowed technological change, in the Ruhr and in other areas of Germany.

Landräte in the Westphalian section of the Ruhr followed a similar path in establishing a mixed corporation. After receiving ministerial permission in December 1905, Gerstein helped build a new company in Bochum that drew on a Westphalian mine for electric power, on Berlin banks for financing, and on electrical manufacturers for expertise. The chairman of the board was Walther Rathenau, director of the Berliner Handelsbank and son of the founder of the electrical manufacturing firm AEG. The chairman of the managing committee was also a director of the AEG's subsidiary for electric light and power companies. The new company, Elektrizitätswerk Westfalen AG, founded in July 1906, combined municipal, county, banking, mining, and electrical manufacturing interests. It rapidly took steps to define a territory from which it could exclude the RWE. ${ }^{33}$

${ }^{30}$ Karl Gerstein, “Anlage eines gemeinsame kommunalen Elektrizitätswerkes für den rheinischwestfälischen Industriebezirk," 25 Nov. 1905, Regierung Düsseldorf 9892, pp. 245-246, HStA Dü; and Gerstein to District President of Düsseldorf, 25 Nov. 1905, ibid., pp. 242-243.

${ }^{31}$ For evaluations of Stinnes's first offer and its rejection see Peters, "Hafenerweiterung Ruhrort," 26 Mar. 1904, Regierung Düsseldorf Präsidialbüro 1068, pp. 17-24, HStA Dü. Also see ibid., pp. 5-13; and Finance Minister, Minister of Public Works, Minister of the Interior, and Minister for Commerce and Industry to Stinnes, 11 Jan. 1906, Regierung Münster 5537, Staatsarchiv Münster.

${ }^{32}$ See Asriel, R.W.E. (cit. n. 21), pp. 10, 14-15; and Richard Passow, Die gemischt privaten und öffentlichen Unternehmungen auf dem Gebiete der Elektrizitäts- und Gasversorgung und des Straßenbahnwesens (Jena: Gustav Fischer, 1912).

${ }^{33}$ Gerstein to District President of Arnsberg, 17 Dec. 1906, KrA 495, pp. 304-306, Stadtarchiv Bochum; Landkreis Bochum, "Verwaltungs-Bericht des Kreis-Ausschußes des Landkreises Bochum," 1906, pp. 48-49, ibid.; and Walter Lipken, Die vereinigten Elektrizitätswerke Westfalen, 
The corporation, like the reorganized RWE, combined business and government in a new institution, and, as in the RWE, business predominated. But unlike the RWE's institutional innovation, innovation in Arnsberg did not go far enough to suit local interests. National electrical and banking corporations provided expertise and financing for the Westphalian mixed company, but they did not protect local municipal and county officials who wanted to force the RWE out of Westphalia. The officials had to take over the company and divide the Ruhr to protect their interests.

\section{DIVIDING THE RUHR}

Landräte, mayors, small manufacturers, and electrical manufacturers in the district of Arnsberg worked together in 1906 to try to find a way of building a new power station or taking over the RWE's second power system near Dortmund in order to provide electricity for the area around Hagen to the south. County and municipal governments provided the forum for debate and negotiations, but different local social and economic interests used the local institutions to pursue different ends. Gerstein's Elektrizitätswerk Westfalen in Bochum represented several county governments, but the electrical manufacturers remained predominant. To the east the city of Dortmund sought to protect municipal interests and the municipal system, which was increasingly insulated from the threat of the RWE by the growing power of the Bochum company. The small manufacturers in and around Hagen who controlled local governments felt themselves squeezed by a heavy industry that provided raw materials and consumed end products. They wanted control of economic and technology policy in their region, but they did not yet have a source of alternating current. ${ }^{34}$ The district president of Arnsberg sought consensus among the three disparate groups to build a company to take over the RWE's Westphalian power system. He had to rely, however, on the ability and willingness of Landräte and mayors to use their roles as heads of local self-government to create new economic organizations.

The Arnsberg president did not have enough administrative power to hold the alliance together. All three groups opposed Stinnes and the RWE, but the small manufacturers in and around Hagen opposed collaboration with anyone in the heavy industrial region and decided in 1907 to establish their own mixed power company. ${ }^{35}$ They succeeded because local county and municipal governments were autonomous enough to work against the district president and communal officials in the heavy industrial section of the Ruhr. The electrical manufacturers in the Bochum company also hindered unified development. Walther Rathenau directed negotiations for Elektrizitätswerk Westfalen but ignored local goals. Landrat Gerstein wanted to make taking over the RWE's second power system

GmbH Dortmund-Bochum-Münster und ihre Entwicklungsgeschichte (Dortmund: Lensing, 1926), pp. 22-27.

${ }^{34}$ On the negotiations see B 3-1977, 1978, and 1983, Stadtarchiv Dortmund; on Hagen see Ludwig Beutin, Geschichte der südwestfälischen Industrie- und Handelskammer zu Hagen und ihrer Wirtschaftslandschaft (Hagen: Linnepe, 1956), pp. 60-141.

${ }^{35}$ See Willi Cuno (mayor of Hagen) to District President of Arnsberg, 30 Jan. 1907, B 3-1978, pp. 382-386, Stadtarchiv Dortmund; and Cuno, "Das kommunal Elektrizitätswerk Mark: Anschluß an ein Verbandswerk oder Bau einer eigenen Zentrale," 3 Feb. 1907, B 3-1977, pp. 204-211, ibid. 
one basis of agreement between the three Westphalian groups, but Rathenau and Bochum's Berlin bankers did not think the investment was necessary. ${ }^{36}$ Rathenau also ignored the interests of local officials in his negotiations with the RWE and Dortmund over territory to be served by the companies and financial arrangements to resolve differences among them. ${ }^{37}$ Westphalian Landräte had not yet found a workable institutional basis for protecting their autonomy through electrification.

By 1909 they had. Landrat Gerstein took over negotiations from Rathenau in late 1907 and set boundaries between electrical supply areas that satisfied his fellow Landräte in Recklinghausen and Gelsenkirchen. He celebrated the agreement as the "second founding" of the Bochum electrical company. ${ }^{38}$ The RWE's position in Westphalia had become untenable. It joined two heavy industrial companies, Dortmund, and Elektrizitätswerk Westfalen in 1908 to form a new mixed company to purchase and operate the RWE's Westphalian power system. The city of Dortmund dominated the new company and used it to build a regional system surrounding the city and county of Dortmund, served by the municipal power company. ${ }^{39}$ There was also a realignment within the Bochum company. Because the Berlin bankers did not protect local interests and because the company drew increasingly on counties for financial support, in 1909 the Landräte of Bochum, Gelsenkirchen, and Recklinghausen decided to buy out the banks' shares in the power company. ${ }^{40}$ The Bochum company was then locally controlled and communally owned, and it could expand in the same manner as did the RWE. Both these firms offered stock and positions on the board to cities and counties as incentives for joining their electric power system. The new mixed structures internalized conflict among institutions as a basis for expanding technological systems, but none of them could unify the Ruhr in one system.

\section{CONCLUSION}

Technological change after 1900 provided the means for building regional technological systems. But those systems did not grow inexorably as a result of the development of new technology. New institutional arrangements were necessary because Germany was divided among a number of large competing institutions

${ }^{36}$ See Döpke's report on the meeting of representatives of Elektrizitätswerk Mark, Elektrizitätswerk Westfalen, and the city of Dortmund, 14 Nov. 1906, B 3-1977, pp. 54-64, Stadtarchiv Dortmund. See also Coels to Walther Rathenau, 28 Nov. 1906, KrA 495, pp. 262-266, Stadtarchiv Bochum; and Gerstein to Rathenau, 19 Dec. 1906, ibid., pp. 308-309.

${ }^{37}$ For local reactions to Rathenau's contract with Stinnes see Landrat in Recklinghausen to Gerstein, 6 Sept. 1907, KrA 496, pp. 116-117, Stadtarchiv Bochum; and Gerstein to District President of Arnsberg, 31 Oct. 1907, ibid., pp. 108-112.

${ }^{38}$ See Gerstein to District President of Arnsberg, 20 Dec. 1907, ibid., pp. 185-186. For the RWE's original demands and the new agreement see Elektrizitätswerk Westfalen to Gerstein, 7 Jan. 1908, ibid., pp. 206-219.

39 For the founding of the new company, the Westfälisches Verbands-Elektrizitätswerk, see District President of Arnsberg to provincial president of Westphalia (von Recke), 11 Apr. 1980, Oberpräsidium 6587, Staatsarchiv Münster; and "1. Aufsichsrats-Versammlung des Westfälischen VerbandsElektrizitätswerkes A.G.," 29 Apr. 1908, B 3-1991, pp. 102-110, Stadtarchiv Dortmund. For the new mixed company's development see Lipken, Vereinigten Elektrizitätswerke Westfalen (cit. n. 33), pp. $10-20$

${ }^{40}$ Karl Gerstein, Albert Hempel, Ludwig LeBret, and Ludwig Aschoff, "Denkschrift über den Erwerb von Akten des Elektrizitätswerk Westfalen durch die Beteiligten Kommunalverbände," 1 Jan. 1909, KrA 501, p. 49, Stadtarchiv Bochum. 
that tried to use the new technology to expand at the expense of other institutions. Cities were growing rapidly and offering new services to their own citizens and to neighbors, many of whom were eventually incorporated into larger cities. County administrations were made up of people who generally shared the opposition of Prussian civil servants to urban concentration and industrial growth. They also sought to overcome the parochial goals of municipal governments that hoped to use municipal monies to solve municipal rather than county or even regional problems. Electrical manufacturers sought the potential profits from building, supplying, and running regional systems. Contingent events influenced development. In the Ruhr, heavy industrialists used electrical technology to promote vertical integration and their power in the region. Municipal and state governments in Westphalia hoped to build their own regional system but built more local ones instead. The RWE was too powerful in the Rhineland, and opposition to it did not overcome all local differences. In the Rhineland, after initial opposition, municipal and county governments began supporting the heavy industrialists.

But not before an institutional innovation. Institutions provided the framework for discussions and fights over electrification. The resolution of the struggle required the development of new, mixed corporations that could combine competing institutions and internalize conflict so that electrification could take place. The RWE began selling stock to cities and counties or exchanging stock for existing facilities. It also placed public representatives on its board. Westphalian interests followed the same tactic. The balance of power in mixed, public-private corporations reflected local conditions in the Ruhr and the rest of Germany. No one institution, new or old, communal or commercial, was powerful enough to force unification of the Ruhr in one technological system. Since institutional relationships were at issue in the deployment of new technology, technological change was inherently political. In building technological systems, Stinnes, Gerstein, and others had to construct new institutional relationships through new business forms. 